Vol. 52, no. 2 (2014), pp. 309-329, doi: 10.14421/ajis.2014.522.309-329

\title{
THE FIQH PARADIGM FOR THE PANCASILA STATE: Abdurrahman Wahid's Thoughts on Islam and the Republic of Indonesia
}

\section{Saefur Rochmat}

Yogyakarta State University, Indonesia

email:rochmat@yahoo.com

\begin{abstract}
The Republic of Indonesia was not established as a purely secular state as muslims constitute the majority of Indonesians. Indeed, they were divided into three main paradigms: secular, theocratic, and fiqh. The Pancasila state was the result of a gentlemen's agreement amongst different muslim groups with different paradigms. The regimes of Soekarno and Soeharto considered that the Pancasila state was unique to the Indonesian character and accordingly these leaders tried to unify these different paradigms following Prof Soepomo's idea of an integralistic state in which the state gives more power to the executive. This idea of an integralistic state is, however, alien to the secular, theocratic, and figh paradigms so that this failed to resolve the conflict. In this regard, Abdurrahman Wabid tries to resolve the ideological conflict by incorporating modern sciences into the fiqh paradigm. This fiqh paradigm has supported the establishment of the Republic of Indonesia, but also, according to Wabid, is able to harmonize secular and Islamic aspirations in the national political system.
\end{abstract}

[Republik Indonesia tidak didirikan berdasarkan konsep murni sebuah negara sekuler karena muslim merupakan mayoritas rakyat Indonesia. Muslim Indonesia terbagi dalam tiga paradigma utama: sekular, teokratik, dan fikih. Bentuk negara Pancasila merupakan hasil kesepakatan ketiga kelompok paradigma tersebut. Regime Soekarno dan Soeharto memahami Negara Pancasila sebagai budaya asli bangsa Indonesia dan mereka berusaba 
menyatukan pendukung ketiga paradigma itu berdasarkan konsep negara integralistic yang diperkenalkan oleh Prof. Soepomo. Namun konsep negara integralistik ini tidak dikenal dalam ketiga paradigm itu, sehingga gagal menyelesaikan konflik. Dalam hal ini Abdurrabman Wabid berusaba menyelesaikan konflik ideologis dengan cara mengadaptasi pengetabuan modern ke dalam paradigma fikih. Paradigma fikih tidak. hanya mendukung berdirinya Republik Indonesia, tetapi juga mampu mengharmoniskan aspirasi sekular dan religius dalam sistem politik nasional.]

Keywords: figh and the state, Indonesian muslim, Pancasila, muslim state.

\section{A. Introduction}

Wahid classifies three paradigms of the relationship between Islam and the state in the modern era: the theocratic view (Islam as religion and state, such as in Saudi Arabia and Iran); the secular view (the separation of religion from state, such as in Turkey); and the fiqh view (mutual legitimacies of religion and state, such as in Indonesia). ${ }^{1}$ The first two views can be categorized as ideological paradigms towards Islam and the state. The first considers the theocratic state as the ideal form of state which should be established, meanwhile the second argues for the ideal form of secular state which should be struggled for. In regard to the ideological paradigm, we may include communism in which the ideal form is the communist state. Supporters of ideological paradigms seek revolutionary changes to those forms of the state which do not fit their ideal. They do not hesitate to use violence for that purpose, for which they try to find justification from their respective ideologies. These three paradigms competed with each other to monopolize the interpretation of Pancasila, the national ideology of the Republic of Indonesia. ${ }^{2}$

The Republic of Indonesia was not established as a pure secular state as Muslims constituted the majority. Not all Muslims educated in Western-style schools supported the idea of a pure secular state as they were preoccupied by the fiqh paradigm. Moreover, some Muslims made

1 Abdurrahman Wahid, "Bagaimana Membaca NU”, in, Gus Dur Menjawab Kegelisahan Umat, ed. by Bagus Dharmawan (Jakarta: Kompas, 2007), pp. 17-8.

${ }^{2}$ An ideological approach may lead to the outbreak of violence if it is understood exclusively so as to stop the process of dialectical dialogues with other ideologies; Stephen Vertigans, "Militant Islam and Weber's Social Closure: Interrelated Secular and Religious Code of Exclusion", Contemporary Islam, vol. 1, no. 4, (2007), p. 303. 
use of the concept of the modern state to implement Shari'a (Islamic) law. Accordingly, the Pancasila state was the result of a gentlemen's agreement amongst different Muslim groups. This kind of solution had been pursued by Snouck Hurgronye, under the auspice of the Netherland East Indies, who tried to separate Islam from politics and just supported Muslims' religious, cultural and educational activities. ${ }^{3}$ It was likely that the Soekarno and Soeharto regimes would have followed this kind of policy, but in fact, they favoured the secular state and tried to marginalize the role of Islam. Accordingly, the three paradigms continued to compete with each other. Indeed, Soekarno had tried to unify these competing ideologies into NASAKOM (Nasionalisme, Agama, dan Komunisme; Nationalism, Religion, and Communism), but this did not work well as NASAKOM was actually based on the idea of Soepomo's integralistic state. ${ }^{4}$ It was not surprising that NASAKOM was a kind of amalgamation of different ideologies and did not have a coherent knowledge system. Soeharto's regime also followed this idea of an integralistic state, which he considered to be the character of Indonesian culture; accordingly, he interpreted Pancasila following this idea of an integralistic state. This idea of integralistic state is alien to the secular paradigm as well as Islamic paradigms. It was not surprising that Abdurrahman Wahid was critical of the Soeharto regime and provided a counter discourse to Soeharto's monolithic interpretation of Pancasila. In this regard, Wahid tried to resolve the conflict in ideologies by means of the fiqh paradigm which supported the establishment of the Republic of Indonesia as he believed that the figh paradigm could harmonize secular and Islamic aspirations in the national political system.

\section{B. The Fiqh Paradigm as a System of Knowledge}

\section{Historical Background of the Birth of the Figh Paradigm}

This figh paradigm was developed by the followers of Sunni to resolve political conflicts wrapped in religious covers. The political crisis arose following the failure of a peace negotiation between Imam Ali, the caliph, and Muawiyah, the governor of Syria. Actually, conflicting

${ }^{3}$ Husnul Aqib Suminto, Politik Islam Hindia Belanda (Jakarta: LP3ES, 1985), pp. $6-7$.

${ }^{4}$ Mujiburrahman, "Islam and Politics in Indonesia: The Political Thought of Abdurrahman Wahid", Islam and Christian-Muslim Relations, vol. 10, no. 3 (1999), pp. 339-52. 
political and religious thoughts arouse following the death of Muhammad the Prophet, but the companions of Muhammad were able to resolve these. In this regard, the khawärij, Imam Ali's former supporters, were upset with the result of the negotiation that slyly removed the status of caliph from Imam Ali and conferred it on Muawiyah. Consequently, they came to believe that those who did not judge affairs based on 'the law of God', namely based on the literal and scriptural verses of the Quran, be considered un-believers (käfir). Accordingly, they tried to kill those involved in the negotiation and were successful in killing Imam Ali.

Internal conflict within the supporters of Imam Ali made them powerless to challenge Muawiyah who tried to justify his rule by developing a theology of jabariyyah (predestination) in which God had predicted his destiny in occupying the office of the caliphate. This theology was challenged by the theology of qadariyah (effort) advocated by the Shiites, the followers of Imam Ali, in that the Muslims had a rational freedom to choose any action, either good or not, but they were responsible for their choices. These Shiites did not want to recognize the leadership of Muawiyah and they were only loyal to their Imam in either religious or political matters. In this regard, the Sunni supported whoever had power to hold the office of the caliphate because in their view the existence of the state was important for maintaining public order which constituted the requirement for religious order. They believed that politics and religion (Islam) were different entities so that there was no relationship between the validity of someone's religious practices and his/her affiliation to the political parties or based on a given theology. ${ }^{5}$

The creation of the Sunni theology was initiated by Abdul Malik bin Marwan, the caliph of the Muawiyah dynasty, who tried to end wars amongst Muslims. It was the idea of al-Hajjaj ibn Yusuf, the general-inchief, who argued that politics should be based firstly on power (machstaat) and secondly on religious rationality. So, the Sunni theology was an attempt by the regime to unite Muslims after its success in crushing the military revolts. This theology facilitated the doctrine of al-tarbi that mentioned the first four caliphs (Abu Bakar, Umar, Utsman, and Ali) at Friday prayer. This doctrine was unbelievable for some people as it did not mention the name of Muawiyah, the founding father of his regime.

${ }^{5}$ Apart of their recognition of political rulers, they distanced themselves from the centre of political power; Mohammad Nadjib, "Menguak Pasang Surut Peran Politik NU”, in Membangun Budaya Kerakyatan: Kepemimpinan Gus Dur dan Gerakan Sosial NU, ed. by Zainal Arifin Toha and M. Aman Mustofa (Yogyakarta: Titian Ilahi Press, 1997), p. 88. 
Indeed, it was the price for unity which should be paid by the regime. This doctrine of al-tarbi was a historical achievement of the Muslims in the quest for consensus. It was followed by the doctrine of al-irja in which only God has the right to judge a Muslim as kafir (un-believer). ${ }^{6}$ By so doing, the Sunnists tried to avoid an ultimate truth claim in this worldly life.

In line with the Sunni tradition, namely the figh paradigm, ${ }^{7}$ Islam and the state constitute different entities, but both should develop mutual legitimacy. ${ }^{8}$ The first constitutes a norm, whose authority relies on morality and the second bases its authority on power. Why does the state rely on power? This is due to the state being the creature of human beings and, accordingly, the state is a part of culture. Accordingly, the figh paradigm tries to relate the binary existence between a norm and culture because it denies the legitimacy of exclusive power based on the survival of the fittest as this would deny the status of human beings. On the other hand, the fiqh paradigm tries to implement a norm, namely Islam, by considering the particularity of a certain culture in order to avoid the outbreak of violence. Recognizing the role of culture in implementing a norm, namely Islam, the figh paradigm accepts the existing culture, including the state, as long as it does not obviously violate Islam. In line with this, the Sunnists, namely the traditionalist Muslims, consider the importance of the state based on its function, not on its form as Islamic or not. Accordingly, traditionalist Muslims accepted the existing Hindu and Buddhist kingdoms when they came to Indonesia for the first time. They, then, also justified the Dutch colonial rule and the Japanese occupation rule, as both functioned as a tool for establishing public order. Last but not least, they supported the establishment of the Republic of Indonesia based on the secular ideology of Pancasila."

${ }^{6}$ Nurcholish Madjid, “Aktualisasi Ajaran Ahlussunnah Waljamaah”, in Islam Indonesia Menatap Masa Depan, ed. by Muntaha Azhari and Abdul Mun'im Saleh (Jakarta: P3M, 1989), pp. 66-70.

${ }^{7}$ Einar M. Sitompul, Nabdlatul Ulama dan Pancasila: Sejarab dan Peranan NU dalam Perjuangan Umat Islam di Indonesia dalam Rangka Penerimaan Pancasila Sebagai Satu-satunya Asas (Jakarta: Pustaka Sinar Harapan, 1989), p. 12.

${ }^{8}$ Abdurrahman Wahid, Mengurai Hubungan Agama dan Negara, ed. by Kacung Marijan and Ma'mun Murod Al-Brebesy (Jakarta: Gramedia Widiasarana Indonesia, 1999), p. 109.

9 Their support of the Republic of Indonesia was analogical to the previous traditionalist muslims who supported the existence of the caliphate of Turkey, although its rulers were not from the Quraisy tribe, from which Muhammad the prophet originates. Indeed, there is a textual argument (al-naqli) in the form of hadith which Al-Jämi'ah, Vol. 52, No. 2, 2014 M/1435 H 


\section{The Fiqh Paradigm as a System of Knowledge}

Wahid argues that traditionalist Muslims advocate the fiqh paradigm and they socialize this paradigm in their pesantren. As I mentioned above, the origin of the figh paradigm, namely the intellectual tradition in pesantren, can be traced to the development of Islamic sciences from the earliest establishment of the Islamic community. This is due to the importance of education in the view of Islam, as can be noticed from some sources of motivation in the Quran and hadiths. The figh paradigm considers the Quran and hadiths as the object of knowledge, not simply as a guide to doing of good deeds, and accordingly, Wahid is very respectful to the Islamic scholars as he expresses in the following statement:

They were people who treat the Quran and hadiths as the object of knowledge, not only as a guide for doing good deeds such as done by Caliph Utsman bin 'Affan who was known as a pious person and finished reading the Quran within a very short period. ${ }^{10}$

The Sunni tradition adopted by traditionalist Muslims, such as the followers of NU, is an accumulation of the manifestation of Sunnist thought over their history. Accordingly, the Sunni tradition responds dynamically to the development of human history. This dynamic tradition is transmitted to the next generation by means of the kitab kuning (religious books, written on the yellow papers). ${ }^{11}$ The Sunni tradition ( $a b l$ al-sunnah wa l-jamāab) considers that all aspects of human life, including state affairs, should apply a religious paradigm, namely the figh paradigm, based on the principles of moderation, tolerance, equality, and justice. Sunnists are also flexible in responding to political issues and do not treat the Quran and hadiths as a kind of ideology. Sunnists have developed religious political thought that is based on three principles:

- the balancing arguments between text (naq) and reason ('aq), but rationality is inferior to the text.

- purifying tawhid (the principle of the Oneness of God) from foreign beliefs and recognize Sufism as long as it is in conjunction with Sharia.

- very careful in the judgement of a muslim for being a musyrik (belief other than in God) and a käfir (un-believers), although he/she has

mentions the leader should come from the Quraisy tribe.

${ }^{10}$ Abdurrahman Wahid, Menggerakkan Tradisi: Esai-Esai Pesantren (Yogyakarta: LKiS, 2001), pp. 157-58.

11 Ibid., p. 158. 
not completely purified his/her tawhid. ${ }^{12}$

The fiqh paradigm, namely the fiqh tradition, is not a relic which is no longer useful, but a tradition used by the clerics to give meaning to reality: a cluster of values and norms used by the clerics to define Islam. ${ }^{13}$ Accordingly, this fiqh tradition is a treasure of history which has had significant meaning for its followers up to now. This tradition is useful to form Muslim identity. Tradition manifests into some symbols (tradition with a small t) which may reduce their significance in the passing of time and space, however, people may reinterpret the symbols in the view of a primordial source (namely Tradition with capital T). Traditionalist philosophers such as Rene Guenon, Frithjof Schuon, Titus Bukhard and Syyed Hossein Nasr believe that Tradition is similar to perennial philosophy whose characters are universal and everlasting. ${ }^{14}$

Wahid is very much appreciated by these traditionalist philosophers and he has translated into Indonesian the work of Syed Hussein Nasr. ${ }^{15}$ In line with this, Wahid tries to revitalize tradition with the development of modern science and technology. Accordingly, Wahid would understand that tradition with a small $\mathrm{t}$ is a kind of a relic which may no longer be useful, but it is possible to give a new meaning to this tradition as Tradition with a capital $\mathrm{T}$ as a kind of methodology which is a useful tool for searching the truth in a new context based on tradition (with a small t). ${ }^{16}$

Wahid argues that the mechanism for the operation of the figh paradigm is by applying usül al-fiqh (Islamic legal philosophy), maxim jurisprudence, and qä idah fiqiyah (principles of Islamic law) $\cdot{ }^{17}$ As such, the figh paradigm can be considered as a kind of knowledge system, such as believed by Clifford Geertz to be a method for how to make sense of

${ }^{12}$ Arland, "Faham Ahlussunnah Wal Jama'ah yang dianut NU", KMNU UPI (9 Apr 2014), http://kmnuupi.org/faham-ahlussunnah-wal-jamaah-yang-dianut-nu/, accessed 12 Mar 2014.

${ }^{13}$ Jajat Burhanuddin, Ulama dan Kekuasaan: Pergumulan Elite Politik. Muslim dalam Sejarah Indonesia, ed. by Testriono, Olman Dahuri, and Irsyad Rhafsadi (Jakarta: Mizan, 2012), p. 8.

${ }^{14}$ Harry Oldmeadow, Frithjof Schuon and the Perennial Philosophy (Bloomington: World Wisdom, 2010), p. 72.

${ }^{15}$ Seyyed Hossein Nasr, Islam: Antara Cita dan Fakta, trans. by Abdurahman Wahid and Hasyim Wahid (Yogyakarta: Pustaka, 2001); Abdurrahman Wahid, Prisma Pemikiran Gus Dur (Yogyakarta: LKiS, 2010)..

${ }^{16}$ Oldmeadow, Frithjof Schuon and the Perennial Philosophy, p. 72; Wahid, Islam Antara Cita, p. 51.

17 Abdurrahman Wahid, Islam Kosmopolitan: Nilai-Nilai Indonesia dan Transformasi Kebudayaan (Jakarta: Wahid Institute, 2007), pp. 32-3. 
what other conceptions of knowledge, of knowing, and of the uses of knowledge could be brought into play. ${ }^{18}$

\section{Islam as the Norm and the Particularity of Indonesian Political System}

The existence of a dialectical stance between the normative of the absolute and the particular of the relative is a kind of historical mission for religious people to do good things in their worldly life. However, Wahid recognized that it is possible for people to believe in materialism, such as Karl Marx, and they may be a success in their worldly affairs, but we do not guarantee that they feel happy in their success, regarding happiness as not only a matter of material achievement. On the other hand, some religious people try to fulfil pure spiritual achievements through practising a series of religious rituals and still pray as a kind of training for sensing the heart. All of these are done to obtain the feeling of happiness without fulfilling material achievements. In this regard Wahid follows the path of Muhammad the Prophet who was not dissolved by spiritual achievement at the time of isrä' mi'rác $j$ and returned to society fulfilling the mission of salvation in this worldly life. ${ }^{19}$ The mission for the development of the human being in this world is the manifestation of God's spirit in all people. It is this spirituality which provided Muhammad the Prophet with the robust stamina and sincere motifs in implementing the mission for human beings.

Believing in both religious and secular knowledge, Wahid believed that happiness should be pursued by fulfilling the demands of material and psychological aspects: It is difficult for people to feel happiness if they are not able to control their ambitions as well as their wills, such as to be loved by someone. I like to call this mission for human beings as the 'civilization mission' in which the Islamic mission benefits not only Muslims but all people without discriminating on the grounds of their primordial background. ${ }^{20}$ It is implicit that the missionary endeavour is not upheld by introducing the normative aspects of religious doctrines,

${ }^{18}$ Clifford Geertz, The Interpretation of Cultures (New York: Basic Books, 1977), pp. 89-91.

${ }^{19}$ Abdul Munir Mulkhan and Muhammad Fahmi, "Islam Ideologi dan Islam Budaya", in Islam Transendental: Menelusuri Jejak-Jejak Pemikiran Islam Kuntowijoyo (Yogyaarta: Pilar Religia, 2005), pp. xxv-xxvi.

${ }^{20}$ Saefur Rochmat, Sejarah Islam Indonesia: Kontinyuitas Tradisi dan Modernisasi (Yogyakarta: BPFSS, 2004), p. 66. 
but by implementing Islamic values in the society to solve human problems. For that purpose, it is required for muslims to acknowledge the secular sciences as a tool, but they should be used in the view of Islamic cosmology. In other words, the civilization mission makes it possible for muslims to cooperate with non-muslims in the efforts to solve human problems. For example, muslims may cooperate with non-muslims to develop democracy in Indonesia.

Regarding the importance of the structural approach in life, Wahid was concerned with the issue of state for its great influence on human life and its position as the peak of the hierarchy of the social system. Moreover, as history shows, the relationship between state and religion has interested many scholars, ${ }^{21}$ such that Wahid he wanted to participate in formulating an ideal framework for the relationship between religion and state. He argued that both should provide mutual legitimacies, although he recognized the importance of secularization, namely the separation of management of the state and religions. On the one hand, he did not agree with the implementation of the legal formal Shari'a in the state because it would hinder people of other religions to participate fully in politics. However, the state should recognize the role of religions as ethical or moral guidance to the running of the state, as well as a non-material necessity for religious people. In line with the concept of the Pancasila state, the Republic of Indonesia accommodates both religious and secular systems of knowledge. For that purpose, the state and religious communities should find a durable solution concerning the proper place of religion in the state: temporary solutions just postpone the real problem and can possibly result in violence. A democratic government, therefore, is pivotal for providing a room for dialogue between government and religious communities, within or of different religions, and individuals.

The fiqh paradigm can function as a method to reconcile the two extreme political paradigms: idealistic and realistic. The former argues that life should be judged according to societal norms, namely values systems, such as Islam, and the latter argues that power should dictate one's life. The idealistic paradigm asks the individual to follow the value system of society, meanwhile the realistic one tends to lead to violence as a result of its emphasis on the enforced survival of the fittest through competition. Meanwhile, Wahid introduces a figh paradigm to bridge the two paradigms. He acknowledges both norms and power as elements of

${ }^{21}$ Wahid, Prisma Pemikiran Gus Dur, p. 1. 
human life and that power should be guided by norms to lead to a peaceful life. However, norms, namely the values system, should be implemented gradually considering their contexts such as situation, condition, and historical background. By doing this, he tries to avoid the outbreak of violence. This is a part of acknowledging that truth, as a norm, is not absolute, as it is contingent upon the contexts, and how this can lead to more peaceful relations. He understands that it is in how the norms or value systems are implemented that tensions and power struggles arise. ${ }^{22}$

The figh paradigm aims to evade the prevalent tension within political philosophy from Plato, Kant, Hegel, Marx, and other modern scholars. The tension roots in acute conflict concerning whether truth already attaches to people as buman nature or is created; integrated within the people's consciousness (bere inside) or discovered and lies out there? Answers to these ontological questions lead us to divide two faculties of political philosophy; the public sphere and the private sphere. The political philosophy that belongs to the private sphere, such as relativism, scepticism, postmodernism (radical scepticism), hermeneutic philosophy, and Wittgenstein's, all of which argue that truth (ethic) integrally exists within the subject so that the task of the subject is not to find out the truth, but to actualize the truth in societal life. On the other hand, political philosophy belongs to the public sphere, and argues that the subject has a task to search for the truth lying out there. In other words, private sphere philosophy tries to discipline itself to actualize the self and claim Nietsche's concept of the superhuman which pretends to make efforts of self-creating (Foucault calls it an aesthetic or technique of self). That is, it is relative and pragmatic. Meanwhile, public sphere philosophy emphasizes creating institutions for social participation with their normative, utopian standards. ${ }^{23}$ These distinctions lead to a dichotomy in the task of political philosophy. The first is focusing on the deconstruction of all forms of politics of the body, language or discourses. Meanwhile, the second is focusing on the grand narrative as well as how to create social structure and emancipative social relations (Habermas' terminology) or justice or fairness (Liberal terms such as used by John Rawls). Most philosophers of this camp claim that the main

${ }^{22}$ Abdurrahman Wahid, Kiai Nyentrik Membela Pemerintab (Yogyakarta: LKiS, 1997), p. 2.

${ }^{23}$ Sinta Nuriyah Rahman and A. Mustofa Bisri, Beyond The Symbols: Jejak Antropologis Pemikiran dan Gerakan Gusdur (Bandung: Remaja Rosdakarya dan INCRëS, 2000), p. 24. 
aim of philosophy can only be noticed from its influences on political output, emancipative and so on, so that philosophy and politics will be useful only to pursue ideal objectives. ${ }^{24}$

Ontologically, based on the elaboration of the distance between subject and truth as well as the subject's task to find truth outside of the self, the public sphere of philosophy claims that the task of sciences, philosophy and theories will be fulfilled only if the subject is able to reach the truth outside. It is because it is a momentum when the subject can claim its moral fulfilment with its ideals. We find this view in Plato's political philosophy of the body to reach the soul, Hegel's concept of absolute truth, Marx's concept of a future communist society as a normative for class struggle in the capitalist era. It is implicit that the idea of progress is accomplished only if the final momentum is achieved (subject=truth), not before that. ${ }^{25}$ Consequently, the supporters of the public sphere do not consider the subject's efforts at discovering the 'time' and the 'distance' which, of course, have changed the subject's character so that the subject at the point of departure is different from the subject at any given time because the subject has moved and experienced certain praxis, namely creating tradition. In this regard, the fiqh paradigm is relevant to the issue of the subject's effort in discovering the 'time' and the 'distance' as it seeks to bridge between the 'norm', namely a value system (such as in the form of Islamic doctrines) and the 'particularity', namely its realization in the Indonesian context. Wahid's figh paradigm can be discerned from his critical evaluation to NU that the same NU is different at different times. For example, NU at the time of its establishment was different from NU during his tenure because, in his opinion, each historical period requires different responses, and is led by different elites. ${ }^{26}$ Accordingly, Islam as norms has been dealing with the particularity of Indonesian culture, including its political system. This implies that both Islam and culture are related mutually. In line with this, Wahid recognized the dichotomy of public and private spheres, but both should relate to each other. Accordingly, he offered a theology of social pillars which recognizes the inter-relationship between the public and private spheres.

In line with principle of mutual relationship between norms and

${ }^{24}$ Robertus Robert, "Emansipasi, Tradisi dan Kontinjensi: Politik Radikal dalam Skeptisisme Neo-Liberal”, Mandatory, vol. 1, no. 1, pp. 14-6.

${ }^{25}$ Ibid.

26 Wahid, Prisma Pemikiran Gus Dur, p. 166. 
the particularity, Wahid believed that religious and secular affairs are not separate. This is implying that Muslims' activities in secular affairs have religious meanings as manifestations of Muslims' surrender to the will of God. This view will put one's worldly activities into the framework of religion, as the normative standard of life. In other words, the Islamic worldview is to actualize a given normative truth dialogically with other values systems and the power in the societies as the contexts for its implementation. This view is critical of Wittgenstein's relativism as Wahid believes that man should find the contextual truths, and then actualize them in societal life. In this regard, Wahid refers to Hasan Hanafi's concept of the active consciousness which consists of motif and action. Both elements are interrelated and form an ideal worldview which harmonizes the normative messages of Islam with their eventual actualizations in societal life over time. ${ }^{27}$

In line with his fiqh paradigm, Wahid developed a dynamic relationship between the state and Islam as he employs a political approach to the existing principle of mutual legitimacy of the figh paradigm. In this regard, he proposes democracy as a quasi-norm, ${ }^{28}$ namely a kind of standard, which should be respected by both the state and its people. His statement on the dynamic relationship between the state and Islam is as follows:

...so that our understanding of the relationship of the state and its people is also dynamic. If the state is able to materialize the certain welfare of its people, this means that the state has accomplished its duty of establishing welfare, ... such as through social insurance. This signifies that the establishment of welfare and justice, ... which both constitute the objective of the Constitution, have been done ... [] $\mathrm{f}$ this is successfully materialized by the Muslim community, this means that Islam has succeeded in providing welfare without becoming a formal system. ${ }^{29}$

\section{The Importance of the Figh Paradigm in Harmonizing Secular and Religious Aspirations}

Wahid believes that the Sunni tradition has a cosmopolitan

\footnotetext{
27 Ibid., p. 47.

28 Wahid, Islam Kosmopolitan, p. 303.

29 Abdurrahman Wahid, Islamku, Islam Anda, dan Islam Kita: Agama Masyarakat Negara Demokrasi (Jakarta: The Wahid Institute, 2006), pp. 94-5. 
character, in that it is willing to absorb other traditions and cultures to suit Islamic cosmology (the figh paradigm). In relation to pluralistic cultures, the Sunni tradition has developed various kinds of fiqh and the Sunni tradition recognizes four schools of Islamic jurisprudence. However, all schools of fiqh base their thoughts on and refer them to the principle of the Oneness of God (tawhid). ${ }^{30}$ Wahid explains that in the $2^{\text {nd }}$ and $3^{\text {rd }}$ century of the Islamic calendar (bijrah) in the Middle East, the clerics played the roles of:

$[\mathrm{H}]$ umanists, in terms of their abilities to master some knowledge of Greek origin .... They adopted and incorporated from outside what they had taken and filtered them through the standard of the Quran and hadiths. The combination of such kinds of humanism and the normative tendency of treating the Quran and hadiths as the formal sources produces a unique attitude: on the one hand, they were scholars who had good reputation; but on the other, they maintained their devotion to the God and did not lose their faith in the face of their massive absorption from other civilizations. ${ }^{31}$

Wahid's belief in the cosmopolitan character of Islam is also shared by Bassam Tibi who argues that Islamic humanism would help to resolve the conflict of civilization between the West and Islam. ${ }^{32}$ However, Tibi is critical of sharia Islam such as his statement as follows:

Unfortunately, the Islamic tradition of humanism was short-lived. The conflict between figh (sacral jurisprudence) and falsafa (rational philosophy), or between theocentrism and humanism, ended with the defeat of the latter, but the consequent decline of Islamic civilization was paralleled by the rise of humanism in Europe. ${ }^{33}$

A similar tone has been raised by Harun Nasution, one of the proponents of Islamic rationalism in Indonesia, who believed that the kitab kuning is not conducive to the development of dynamic and creative thinking. In this regard, Wahid responded that:

Harun Nasution's accusation is not strange and it is not something new. This is only the continuation of a series of a negative campaigns on the kitab kuning (religious books written in yellowish paper) with its system

30 Wahid, Menggerakean Tradisi, pp. 159-61.

${ }^{31}$ Ibid., p. 161.

${ }^{32}$ Bassam Tibi, "Bridging the Heterogeneity of Civilisations: Reviving the Grammar of Islamic Humanism", Theoria: A Journal of Social and Political Theory, vol. 56, no. 120 (2009), pp. 65-80.

33 Ibid., p. 67. 
of religious thought, namely the traditionalism of santri. Indeed, all products of the kitab kuning are only repetition of the established Islamic sciences, which were called the fourteen branches of Islamic sciences by al-Sayuti in his book Itmàm al-Dirāyah five hundred years ago. Based on this consideration, those who want to modernize religious thoughts consider that the kitab kuning is a sign of congealment of thoughts which cause them to be left by other communities. Accordingly, the kitab kuning was blacklisted as literature that was no longer useful. Their attitudeswere not based on a holistic reality and, accordingly, were not relevant to the complexities of realities of everyday life. However, the pesantren community have also changed their way of thought and worldview. ${ }^{34}$

Wahid believed that the fiqh paradigm is the true Islamic worldview in regard to its main character of developing spiritual life. He considered that knowledge has an esoteric dimension because of its relation to the understanding of God. This esoteric character is not pursued by rational orientation, although it possesses a rational dimension. Wahid was very concerned with this spirituality and it even manifested in the institution involving non-muslims, namely LibForAll, in which he uses it to encourage people's awareness of having the spiritual ability to be transformed into individual or social life. Meanwhile its objective is to spread the vision of peace (al-nafs al-mutma'inna) or good behaviour to people, as the representation of spirituality or the true khalifat Allah (God's representative in the world) such as that of the Pandawa in the Mahabarata story of Hindu tradition. ${ }^{35}$

Wahid agrees with D.B. MacDonald that "Shari'ah (Islamic Law) is the science of all things, human and divine". ${ }^{36} \mathrm{He}$ understood that Shari'a consists of both the secular and the sacred aspects of life and consequently it requires the continuing efforts of reinterpretation. ${ }^{37}$ For that purpose, he introduced an Islamic renewal with the terminology of dinamisasi (dynamism) which assumes the two simultaneous processes that are "maintaining the relevant old values and adopting the new ones". Its process is called modernization. ${ }^{38} \mathrm{He}$ understood modernization

34 Syaiful Arif, Gus Dur dan Ilmu Sosial Transformatif: Sebuah Biografi Intelektual (Jakarta: Koekoesan, 2009), p. 234.

35 Abdurrahman Wahid, Ilusi Negara Islam: Ekspansi Gerakan Islam Transnasional di Indonesia (Jakarta: The Wahid Institute, 2009), pp. 12-3.

36 Wahid, Prisma Pemikiran Gus Dur, p. 35.

${ }^{37}$ Abdurrahman Wahid, "Pribumisasi Islam", in Islam Indonesia Menatap Masa Depan, ed. by Muntaha Azhari and Abdul Mun'im Saleh (Jakarta: P3EM, 1989), p. 86.

${ }^{38}$ Wahid, Menggerakekan Tradisi, p. 38. 
as pribumisasi (Indonesianization), in regard to its consideration of Indonesian culture, including its political system, in the process of modernization. He argued that pribumisasi is unavoidable when religion interacts with culture. Indeed, both have independence, but are mutually interrelated. It is not a kind of syncretism for dissolving the norms into the culture, but, on the contrary, how the norms take into account the particularities of the culture as their medium.

A recent issue for Islam in Indonesia is also related to the context of the modern era, namely the issue of modernization, which values highly the concept of the modern state. In this regard, Wahid criticizes the theory of secularization which separates the public sphere from the private one. He only agrees with the theory of secularization in terms of separating the leadership of public sphere from the private one, but both should develop mutual legitimacy. He believes that this understanding of secularization had been pursued by traditionalist Muslims, especially NU, when they supported the establishment of the Republic of Indonesia. Wahid's understanding of the theory of secularization accommodates Muslims who believe that Islam, as a norm, should guide worldly life, including the political system, which tends to rest on the survival of the fittest. Regarding the limitation of the concept of nation state, Wahid does not want to implement Shari'a law formally, but substantively. ${ }^{39}$

In Wahid's view, Islamic teaching can be divided between the fundamental values and the framework for its operation. The fundamental value is the values which support the existence of the society, which are justice, equality, and democracy (according to Muhammad Abu Zahrah and other scholars). The principal mechanism for the operationalisation of these values has been formulated in the form of the maxim of 'tasarruffu al-imam 'ala ra'iyyatibi manutun bil maslahah' (the justification of the ruler actions depends on his/her ability to sustain well beings and welfare) - the values of democracy, justice, freedom, and equality in modern terminology. In line with this, Islam accommodates the realities as long as they support peoples' wellbeing. This principle should be manifest in all realities, both in institutions and the product of law. ${ }^{40}$

Wahid tried to develop the figh paradigm by adapting the development of modern sciences and philosophy as a tool for implementing Islamic values. Based on the figh paradigm, Wahid recognized two different aspects of science, namely material and spiritual sciences. This implies that

39 Wahid, Ilusi Negara Islam, pp. 12-3.

${ }^{40}$ Wahid, "Pribumisasi Islam", pp. 91-2. 
Wahid acknowledges both the empirical method and the consciousness method as a way to acquire science. Through synergy of the sciences, he endeavoured to integrate the empirical sciences into the spirit of God. This figh-plus paradigm is similar to Bassam Tibi's idea of Islamic humanism which would function as 'cross-cultural international morality', in which he appreciates Ibn Rushd's idea of double truth as follows:

Such morality would bring to the fore the work of the first and greatest Islamic political philosopher, al-Farabi ... It would also remind scholars of the value that Europeans conferred on the work of the humanist philosophers ... in particular of Ibn Rushd's teachings about the baqiga al-muzdawaja (double truth), which differentiated between philosophical or rational knowledge and religious beliefs or divine revelation and paved the way for modern European rationalism. ${ }^{41}$

This implies that Wahid does not rely solely on rational thinking which tends to develop into an ideological paradigm. In line with the figh paradigm, Wahid questioned the role of an ideological approach to the life such as written in his article titled "Dimensi Kebalusan Budi dan Rasa" (The Dimension of Refined Mind and Feeling). ${ }^{42}$ This article focuses on the important role of the heart which would create meaningful human beings, living in harmony. This article was to criticize those who value highly the role of ideologies and who, accordingly, consider life is based on the formal truth of ideologies, and thus, in Wahid's view, full of conflicts. In the view of ideology, life would be full of regulations and just based on mathematical calculation, which would cause a deficit in the meaning of life. This kind of thought tended to value highly the role of reason for solving the problems of human beings. In fact, some modern sciences and technologies are not able to handle all the problems of human beings and very often, they have a negative impact on society. Accordingly, people should take into consideration the principle of harmony without which life would be unbalanced as it ignores the true heart. ${ }^{43}$ For Wahid, life was not only directed by the certainty of the formal ideological truth: in fact, there are some aspects of human life which should be taken into consideration such as the feeling of uncertainty and of emptiness which would sharpen human beings' sense of feeling. This would direct people

${ }^{41}$ Tibi, "Bridging the Heterogeneity of Civilisations", p. 69.

${ }^{42}$ Abdurrahman Wahid, Islam, Negara, dan Demokrasi: Himpunan Percikan Perenungan Gus Dur (Gugus Gagas Politik), ed. by Imam Anshori Saleh (Jakarta: Erlangga, 1999), pp. 79-82.

43 Ibid. 
to the consciousness of God, the only certain and absolute. ${ }^{44}$ This writing implies that all ideologies should develop the principle of mutual give and take relevant to solving the problems of human beings.

Wahid considers that the religious science, namely Sufism, either its praxis or its speculativeness, has a central role in integrating various kinds of intellectual paradigms as well as unifying different kinds of Muslim communities. ${ }^{45}$ Practical Sufism encourages people to engage in social activities sincerely, while the speculative Sufism enables people to integrate their intellectual curiosity with the spirit of the God. Wahid understands Sufism along with perennial philosopher Syyed Hossein Nasr who stresses the unity of religions. Both understand religion as comprising two aspects that are exoteric and esoteric. At the exoteric level religion manifests into various kinds of identities so that there are a lot of religions such as Judaism, Christianity, and Islam with their unique characteristics. It is also applied to any kind of religion which is likely to manifest into various kinds of characteristics which are inherently facilitating the birth of different sects as well as of different religious groups or communities. For example, Islam has witnessed the birth of some sects such as Sunni, Shiite, and Khawarrï, meanwhile Indonesian Islam has witnessed different religious groups such as NU, Muhammadiyah, and Partai Keadilan Sejabtera (PKS, Justice and Welfare Party). At the esoteric level all forms of religion share the same spirituality from God. Accordingly perennial philosophers are convinced that the plurality of religions is to do, inherently, with the plurality of human characters. ${ }^{46}$ This directs Wahid to believe that the institutionalization of Islam is related to the secular aspect that Islam as a norm should deal with the particularities of worldly affairs. This implies that Islam has been interpreted following the interest of the dominant actors in a given time in a certain region. Accordingly, Wahid made Muslims aware of the need to reinterpret Islam continuously in the spirit of Islamic societal life.

As a consequence of Wahid's fiqh paradigm, he does not adopt Sufism without reserve, so that the manifestation of Sufism in the public

44 Ibid.

45 This is stated by Wahid in his introduction to the translation of Nasr, Islam Antara Cita, p. xiii.

${ }^{46}$ Nasr, Islam dalam Cita dan Fakta. However, Wahid is critical of Nasr's overemphasis on the contemplative aspect of Islam and on the idealization of Islamic traditionalism. Wahid criticizes correctly that Nasr has avoided confronting some aspects of the development of Islam such as between figh and Sufism so that a lot of lessons from the dynamic of Islam have been neglected. 
should be negotiated with the accepted Sharia by the society. Wahid believes that Sufism is a further development of Shari'a in the form of spiritual refinement for the individual, but its manifestation in the societal life is subjugated to the particularity of its context. Indeed, he believes that the fiqh paradigm requires a dialectic between individual and society, an element of his conviction that belief has absolute character at the individual level. It is implicit that man/woman should develop an internal dialectic between the absolute, namely the normative, and the particular of the given society. Wahid formulates this dialectical relationship between individual and society into the pillar of social life (rukun sosial) which mediates the individual characters of the pillars of belief (rukun iman) and the societal characters of the pillars of Islam (rukun Islam) ${ }^{47}$ He believes that rukun sosial is consistent with the principle of al-shürä (deliberation), which is similar to the liberal democracy in the modern political system. ${ }^{48}$

\section{E. Concluding Remarks}

Wahid understands Islam from the view of the figh paradigm which recognizes Islam and the societal system, including political system, as different entities and in which both should develop mutual legitimacy. This implies that the figh paradigm recognizes two different aspects of science, namely material sciences (i.e. secular sciences) and spiritual ones. Accordingly, he adapts the development of modern sciences into the figh paradigm which would enable Muslims to participate actively in the modern political system. In line with this, he accepts liberal democracy, as the implementation of the principle of shura (deliberation) in the modern era. He argues that democracy is a kind of quasi-norm, namely a kind of standard, which should be respected by both the state and its people. This idea of democracy enables both the state and Muslims to develop a mutual legitimacy. ${ }^{49}$

Wahid believed that modern sciences are crucial to support the existence of people in this worldly life, but he, as a Muslim, believed that Islamic cosmology directed him in his thought about the secular sciences. Moreover, his rationality does not always find logical argument in modern sciences, but finds its foundation in the integrality of the religious sciences. ${ }^{50}$ Consequently, Wahid tries to create dialogue within

${ }^{47}$ Wahid, Menggerakean Tradisi, p. 148.

${ }^{48}$ Wahid, Mengurai Hubungan Agama, pp. 53-4.

${ }^{49}$ Ibid., p. 109.

${ }^{50}$ Wahid, Kyai Nyentrik, p. 33. 
himself between the religious and the secular sciences for the purpose of implementing the truth through realistic actions in worldly life. What he is doing in life is to find a balance between the normative aspect of the religion and the freedom of thinking in matters of secular affairs. Accordingly, he understands life as the ability to relate the spiritual vision of God to the deeds and behaviours of human beings in worldly life. For him, life is a long journey to find the truth ${ }^{51}$ as well as to implement it into life, with patience, in the pursuit of progress. ${ }^{52}$ For that purpose, he behaves patiently to avoid the side effect of violence which is, of course, a contradiction in terms in relation to humanism..$^{53}$

${ }^{51}$ Syafii Ma'arif, Islam dan Politik di Indonesia: pada Masa Demokrasi Terpimpin (Yogyakarta: IAIN Sunan Kalijaga Press, 1988), p. 5.

52 Wahid, Islamku, Islam Anda, dan Islam Kita, p. 229.

53 Wahid, Prisma Pemikiran Abdurrabman Wabid, at p. 21. 


\section{BIBLIOGRAPHY}

Arif, Syaiful, Gus Dur dan Imu Sosial Transformatif: Sebuah Biografi Intelektual, Jakarta: Koekoesan, 2009.

Arland, "Faham Ahlussunnah Wal Jama'ah yang dianut NU", KMNU UPI, 9 Apr 2014, http://kmnuupi.org/faham-ahlussunnah-waljamaah-yang-dianut-nu/, accessed 12 Mar 2014.

Burhanuddin, Jajat, Ulama dan Kekuasaan: Pergumulan Elite Politik Muslim dalam Sejarah Indonesia, ed. by Testriono, Olman Dahuri, and Irsyad Rhafsadi, Jakarta: Mizan, 2012.

Einar M. Sitompul, Nabdlatul Ulama dan Pancasila: Sejarah dan Peranan NU dalam Perjuangan Umat Islam di Indonesia dalam Rangka Penerimaan Pancasila Sebagai Satu-satunya Asas, Jakarta: Pustaka Sinar Harapan, 1989.

Geertz, Clifford, The Interpretation of Cultures, New York: Basic Books, 1977.

Ma'arif, Syafii, Islam dan Politik di Indonesia: pada Masa Demokrasi Terpimpin, Yogyakarta: IAIN Sunan Kalijaga Press, 1988.

Madjid, Nurcholis, "Aktualisasi Ajaran Ahlussunnah wal Jama'ah", in Islam Indonesia Menatap Masa Depan, ed. by Muntaha Azhari and Abdul Mun'im Saleh, Jakarta: P3M, 1989.

Mujiburrahman, "Islam and Politics in Indonesia: The Political Thought of Abdurrahman Wahid", Islam and Christian-Muslim Relations, vol. 10, no. 3, 1999, pp. 339-52 [http://dx.doi. org/10.1080/09596419908721191].

Mulkhan, Abdul Munir and Muhammad Fahmi, "Islam Ideologi dan Islam Budaya", in Islam Transendental: Menelusuri Jejak-Jejak Pemikiran Islam Kuntowijoyo, Yogyaarta: Pilar Religia, 2005.

Nadjib, Mohammad, "Menguak Pasang Surut Peran Politik NU", in Membangun Budaya Kerakyatan: Kepemimpinan Gus Dur dan Gerakan Sosial NU, ed. by Zainal Arifin Toha and M. Aman Mustofa, Yogyakarta: Titian Ilahi Press, 1997.

Nasr, Seyyed Hossein, Islam: Antara Cita dan Fakta, trans. by Abdurahman Wahid and Hasyim Wahid, Yogyakarta: Pustaka, 2001.

Oldmeadow, Harry, Frithjof Schuon and the Perennial Philosophy, Bloomington: World Wisdom, 2010. 
Abdurrahman Wahid's Thoughts on Islam

Rahman, Sinta Nuriyah and A. Mustofa Bisri, Beyond The Symbols: Jejak. Antropologis Pemikiran dan Gerakan Gusdur, Bandung: Remaja Rosdakarya dan INCRëS, 2000.

Robert, Robertus, "Emansipasi, Tradisi dan Kontinjensi: Politik Radikal dalam Skeptisisme Neo-Liberal", Mandatory, vol. 1, no. 1, pp. 13-29.

Rochmat, Saefur, Sejarah Islam Indonesia: Kontinyuitas Tradisi dan Modernisasi, Yogyakarta: BPFSS, 2004.

Suminto, Husnul Aqib, Politik Islam Hindia Belanda, Jakarta: LP3ES, 1985.

Tibi, Bassam, "Bridging the Heterogeneity of Civilisations: Reviving the Grammar of Islamic Humanism", Theoria: A Journal of Social and Political Theory, vol. 56, no. 120, 2009, pp. 65-80 [http://dx.doi. org/10.3 167/th.2009.56 120].

Vertigans, Stephen, "Militant Islam and Weber's Social Closure: Interrelated Secular and Religious Code of Exclusion", Contemporary Islam, vol. 1, no. 3, 2007, pp. 303-21 [http://dx.doi.org/10.1007/ s11562-007-0027-6].

Wahid, Abdurrahman, Gus DurMenjawab Kegelisahan Rakyat, ed. by Bagus Darmawan, Jakarta: Harian Kompas, 1997.

----, Kiai Nyentrik Membela Pemerintah, Yogyakarta: LKiS, 1997.

----, Mengurai Hubungan Agama Dan Negara, ed. by Kacung Marijan and Ma'mun Murod Al-Brebesy, Jakarta: Gramedia Widiasarana Indonesia, 1999.

----, Islam, Negara, dan Demokrasi: Himpunan Percikan Perenungan Gus Dur (Gugus Gagas Politik), 1st edition, ed. by Imam Anshori Saleh, Jakarta: Erlangga, 1999.

-----, "Pribumisasi Islam", in Islam Indonesia Menatap Masa Depan, ed. by Muntaha Azhari and Abdul Mun'im Saleh, Jakarta, P3M, 1989.

----, Menggerakkean Tradisi: Esai-Esai Pesantren, Yogyakarta: LKiS, 2001.

----, Islamku, Islam Anda, dan Islam Kita: Agama Masyarakat Negara Demokrasi, Jakarta: The Wahid Institute, 2006.

----, Islam Kosmopolitan: Nilai-Nilai Indonesia dan Transformasi Kebudayaan, Jakarta: Wahid Institute, 2007.

----, Ilusi Negara Islam: Ekspansi Gerakan Islam Transnasional di Indonesia, Jakarta: The Wahid Institute, 2009.

----, Prisma Pemikiran Gus Dur, Yogyakarta: LKiS, 2010. 